\title{
Feed utilization and rumen microbial ecology of lambs consuming Daniellia Oliveri seed based diet
}

\author{
Okunade S.A. *1, Isah O.A.2, Odedara 0.0. ${ }^{3}$, Adebayo K.O ${ }^{2}$, and \\ Olafadehan O.A. 4
}

*Corresponding author: saokunade2013@gmail.com

\begin{abstract}
${ }^{1}$ Department of Animal Production Technology, Federal College of Wildlife Management, New Bussa, affiliated to Forestry Research Institute of Nigeria

${ }^{2}$ Department of Animal Nutrition, Federal University of Agriculture, Abeokuta, Nigeria

${ }^{3}$ Department of Microbiology, Federal University of Agriculture, Abeokuta, Nigeria

${ }^{4}$ Department of Animal Science, University of Abuja, Abuja, Nigeria.
\end{abstract}

\section{ABSTRACT}

This study investigated the effects of replacing processed Daniellia oliveri seed meal (PDS) for groundnut cake (GNC) in the concentrate diets of Yankasa male lambs ( 6 months old, body weight of $13.70 \pm 0.1 \mathrm{~kg}$ (body weight)) on feed intake, rumen fermentation parameters and microbial population. Four diets were formulated to contain $0,50,100$ and $150 \mathrm{~g} / / \mathrm{kg}$ PDS to replace 0 , 25, 50 and $75 \%$ GNC (dry matter (DM) basis) in a complete randomized design with five animals per diet. Total DM intake (g/kg BW0.75), ruminal volatile fatty acids, valerate and fungal population linearly increased but ruminal NH3-N, acetate, acetate: propionate, methane production and Entodinium (as \% of the total protozoa count) linearly decreased with increasing PDS level $(\mathrm{P}<0.01)$. Whereas, intake of concentrate, total DM $(\mathrm{g} / \mathrm{d}$ and $\mathrm{g} / \mathrm{kg} \mathrm{BW}$ ), average daily weight gain, ruminal $\mathrm{pH}$, butyrate, iso-valerate, total bacterial count, proteolytic and amylolytic bacterial counts increased linearly and quadratically, basal roughage intake, protozoal count, cellulolytic bacterial count, methanogen count, Diplodinium and Holotrichs (as \% of the total protozoa count) decreased linearly and quadratically $(\mathrm{P}<0.05)$ with increasing PDS level. Feed conversion was lowest ( $\mathrm{L}$ and $\mathrm{Q}: \mathrm{P}<0.01$ ) for PDS15. Ruminal Ophryoscolex (as \% of the total protozoa count) was lower (Q:P $<0.0001$ ) for PDS15 than for other diets. Dietary inclusion of $150 \mathrm{~g} / \mathrm{kg}$ Daniellia oliveri seed meal to replace 75\% DM of groundnut cake in the diet of Yankasa lambs improved intake, rumen fermentation and microbial ecology and weight gain.

Keywords: condensed tannins, weight gain, rumen fermentation, rumen microbiota, methane, Daniellia 


\section{INTRODUCTION}

The rumen is endowed with a composite community of microbes (anaerobic bacteria, protozoa, fungi, methanogenic archaea and phages) whose major function is fermentation of plant materials ingested by the animals. This symbiotic relationship furnishes the host animal with metabolic energy and concomitant methane production in the rumen which is energy loss to the animal. The understanding of dynamic rumen ecosystem can be harnessed in ruminant nutrition for an increased production to satisfy global protein demand, whilst ensuring minimal environmental impact. Many studies report several attempts to exploit plant secondary metabolites (PSM) as natural feed additives to modulate rumen ecology for improved rumen fermentation efficiency, protein and energy metabolism, and improved animal health and productivity and methane mitigation (Benchaar et al., 2007). The anti-microbial and anti-nutritional properties of PSM made them to be regarded as anti-nutritional factors for decades (Patra et al., 2017). Different processing methods including milling, soaking toasting, decortications, cooking etc have been reported to reduce anti-nutritional factors. However, polyphenols and tannins retain their inhibitory properties even after heat treatment. Since the PSM mode of anti-microbial action is highly specific, they can be exploited in modulating rumen microbial ecosystem for better feed utilization and performance by the host animal.

Daniellia oliveri, a tanniniferous evergreen leguminous tree belonging to the family Caesalpiniaceae, is a copiously available tree in the savannah area of Nigeria (Okunade et al., 2014b, 2019; Olafadehan et al., 2020). Previous studies (Okunade and Olafadehan, 2019) on the nutritive value of Daniellia seed meal indicated its potential as an alternative protein source to the expensive and occasionally scarce conventional protein sources such groundnut cake, soybean cake, etc. in livestock production. However, like other tropical legume seeds, it contains high levels of PSM (tannins, saponins and other anti-nutritive factors). Plant secondary metabolites, particularly condensed tannins (CT), could induce intoxication if consumed in excess (Olafadehan et al., 2014a; Okunade et al., 2014a), altering ruminal microbiota population and activity and affecting performance of animals. Due to its content of PSM, processed Daniellia oliveri seed meal (PDS) can be used as a protein source in the diet of ruminants to modulate rumen microbiota and thus improve feed utilisation, ruminal fermentation efficiency and growth performance, and mitigate methane production. Few studies have considered the effect of replacing secondary metabolites free conventional protein source, such groundnut cake (GNC), with PSM containing alternative protein ingredient. Information on the effect of feeding tannin-containing PDS, as a 
protein source, to modulate ruminal microflora with the aim of altering ruminal fermentation and improve performance of sheep is very scarce. The current study evaluated the effect of replacing GNC with PDS in the supplementary diet of growing lambs on feed utilisation, ruminal microbiota and fermentation and growth performance.

\section{MATERIALS AND METHODS}

\section{Experimental site, animals and management}

The experiment was carried out at the small ruminant unit of the Teaching and Research Farm, Federal College of Wildlife Management, New Bussa, Niger State Nigeria. The study area location (latitude: $9^{\circ} 53^{\prime}$ and $10^{\circ} 00^{\prime \prime}$ $\mathrm{N}$ and longitudes $4^{\circ} 31^{\prime}$ and $40^{\circ} 33^{\prime \prime} \mathrm{E}$ ) is in the guinea savannah agroecological zone of North central part of Nigeria. It has a mean annual temperature of about $37.2^{\circ} \mathrm{C}$, with relative humidity of about $60 \%$ and the mean annual rainfall value is about $1109 \mathrm{~mm}$ (Okunade et al, 2019).

Twenty healthy growing Yankasa intact male lambs (6 months old, body weight, $13.7 \pm 0.1 \mathrm{~kg}$ ) were stratified into four groups of five animals of similar body weight (BW) per group in a completely randomized design. They were housed individually in a clean, well-ventilated, half-walled and rammed floored bedded with softwood shaving pens. All male lambs were quarantined and fed with experimental diets for four weeks; they were intramuscularly injected and dewormed with $1 \mathrm{~mL} / 10 \mathrm{~kg}$ BW of oxytetracycline and levamisole respectively and sprayed against external parasites with diazuntol.

\section{Seed collection and processing}

Seeds of Daniellia oliveri were collected from the established plots of Daniellia oliveri plants within the premises of the Federal College of Wildlife Management, New Bussa Nigeria. The forest conservation was established many years ago for the purpose of wildlife and soil conservation to prevent desertification and act as wind break. The dehiscent seeds of Daniellia oliveri were gathered from the ground, cleaned from extraneous materials and sun dried. The seeds were toasted by placing big round iron cooking pot containing sand upon a tripod stand under which fire was made with wood. Dried clean D. oliveri seeds were added to sand in ratio 2:1 (w/w). The sand and seeds mixture were heated under controlled temperature (not exceeding $80^{\circ} \mathrm{C}$ ) and frequent stirring was done to ensure even toasting for 30-35 minutes until the seeds cracked and their white endosperm turned brown with appealing aroma. The seeds were carefully separated from the sand, allowed to cool and cracked exoderm was carefully removed (decorticated) manually. The processed seeds were ground in a hammer mill (Model W-6-H, Buffalo NY 14206) to pass through a $1 \mathrm{~mm}$ sieve particle size, and tagged 
processed D. oliveri seed meal (PDS). The seed meal was stored in air -tight containers until ready for use.

\section{Experimental diets}

Four iso-nitrogenous concentrate diets; (160 g/kg CP on DM basis) were formulated such that (GNC, a conventional protein source) in the control diet was replaced with the PDS meals at 0, 25, 50 and 75\%, and the dietary treatments were designated PDS0, PDS25, PDS50 and PDS75, respectively. Each of the lambs was offered $1 \mathrm{~kg}$ of concentrate once daily at 09:00 h, while the basal diet, a low-quality threshed sorghum tops (TST), was offered ad libitum throughout the twelve weeks experimental period. Clean water was provided ad libitum daily.

\section{Rumen fermentation parameters}

About $100 \mathrm{~mL}$ of representative rumen liquor was collected before morning feeding on the last day of the experiment from each lamb via stomach tube. Temperature and $\mathrm{pH}$ of rumen liquor were determined immediately after collection using a portable digital $\mathrm{pH}$ and temperature metre model CT 6020. The rumen liquor was strained through four layers of muslin cloth, preserved by adding a few drops of saturated mercury (II) chloride solution, placed, taken to the laboratory and frozen at $-30{ }^{\circ} \mathrm{C}$ pending analysis. Samples were analysed for ammonia nitrogen using micro Kjedahl method (AOAC, 2000) immediately on getting to the laboratory. Total volatile fatty acids in SRL were determined by steam distillation process as described by Keyol and Borilek, (1995). Individual volatile fatty acids (VFA; acetic, propionic and butyric acids) were determined using gas chromatography as described by (Mebrahtu, 1992).

\section{Rumen microbial enumeration and isolation}

Samples of strained rumen fluid were analysed in triplicate. Total viable bacteria and fungi were enumerated by the method of Joblin (1981), respectively, using anaerobic roll tubes. Total protozoa population in the rumen fluid was determined using a Sedgewick-Rafter counting chamber (Dehority et al., 1989) with the modifications proposed by D'Agosto and Carneiro (1999), and the protozoa present in each sample were isolated based on the criteria described by Ogimoto and Imai (1981). The bacteria isolation was conducted using conventional techniques of serial dilutions and repeated tubing of the selectively enriched microbial cultures by using the specific media for rumen bacteria. Strict anaerobic conditions were maintained during the isolation procedure by continuous flushing of the rumen fluid with $\mathrm{CO}_{2}$ gas. The growth media contained $15 \mathrm{~mL}$ mineral solution I $\left(\mathrm{KH}_{2} \mathrm{PO}_{4} 3.0 \mathrm{~g}\right.$; $\left(\mathrm{NH}_{4}\right)_{2} \mathrm{SO}_{4} 6.0$ g; $\mathrm{NaCl} 6.0 \mathrm{~g} ; \mathrm{MgSO}_{4} 0.6 \mathrm{~g} ; \mathrm{CaCl}_{2} \cdot{ }_{2} \mathrm{H}_{2} \mathrm{O} 0.795 \mathrm{~g}$ per Litre), $15 \mathrm{ml}$ mineral solution II $\left(\mathrm{K}_{2} \mathrm{HPO}_{4} 3 \mathrm{~g} /\right.$ litre $), 0.25 \mathrm{~g}$ yeast extract, $1 \mathrm{~g}$ tryptone, $0.1 \mathrm{ml}$ 
resazurine (0.1\%), $0.2 \mathrm{ml}$ hemin $(0.05 \%), 0.5 \mathrm{~g}$ microcrystalline cellulose, 0.1 g cellobiose, $0.4 \mathrm{~g}$ sodium carbonate, $20 \mathrm{ml}$ clear rumen Fluid, $50 \mathrm{ml}$ distilled water and $50 \mathrm{mg}$ cysteine hydrochloride.

\section{Chemical analysis and calculations}

Processed Daniellia oliveri seed meals (PDS), basal (TST) and the Daniellia oliveri seed-based concentrate diets were analysed for their proximate constituents according to the method of AOAC (2000). Neutral detergent fibre (NDF), acid detergent fibre (ADF) and acid detergent lignin (ADL) were determined by methods of Van Soest et al. (1991). Cellulose and hemicellulose were estimated as differences between ADF and lignin and NDF and ADF, respectively. Total condensed tannins were determined as reported by Polshettiwar et al. (2007). Methane production was estimated by the equation of Moss et al. (2000).

Estimated $\mathrm{CH}_{4}$ production $=0.45$ (acetate) -0.275 (propionate) +0.5 (butyrate)

\section{Statistical analysis}

Data were subjected to one way of ANOVA in completely randomized design using version 6 of SAS software (SAS Institute, 2012). Significance difference between individual means was separated by Duncan's procedure of the same software. Treatments means were considered significant at $\mathrm{P}<0.05$, while polynomial (linear and quadratic) contrasts were used to examine the variable responses to increasing level of PDS in the diets.

\section{RESULTS}

\section{Nutrient composition of experimental concentrate diets}

Dry matter content ranged from $842.8 \mathrm{~g} / \mathrm{kg}$ DM in PDS25 to $872.9 \mathrm{~g} / \mathrm{kg}$ DM in PDS50. Whereas OM and NFC increased, ether extract (EE), NDF and ADF decreased with increasing replacement of GNC with PDS $(\mathrm{P}<0.05)$. Diets were isonitrogenous. Condensed tannins were higher $(\mathrm{P}<0.05)$ for PDS15 than PDS5 and PDS10. PDS is a good quality feedstuff with a high crude protein (CP), low neutral detergent fibre and moderate CT. The basal TST had a low CP and high CT and NDF (Table 1). 


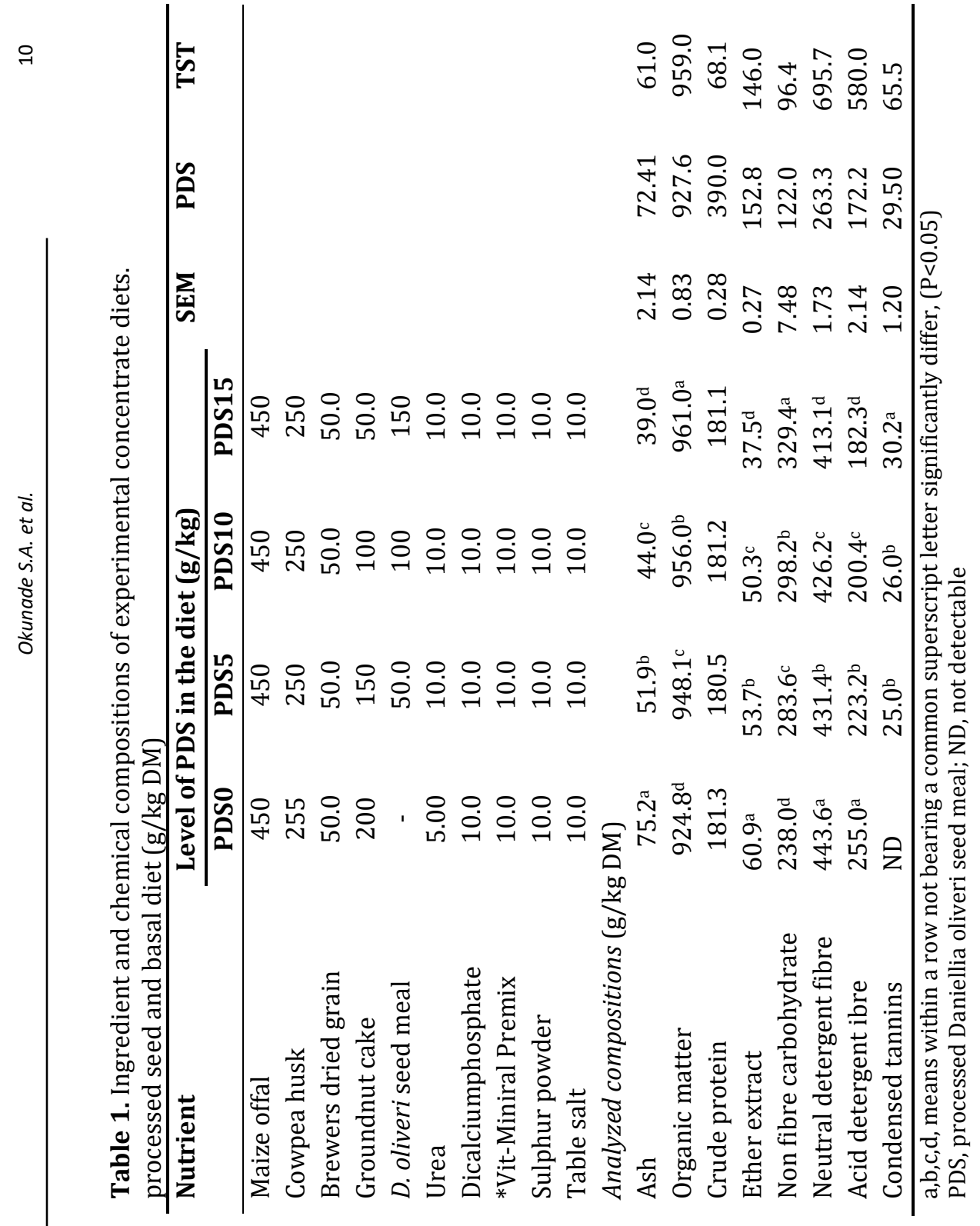




\section{Feed utilisation}

Intake of TST and feed conversion decreased (L: $P<0.0001$; $\mathrm{Q}: P<0.01$ ) as the inclusion of PDS in the concentrate increased (Table 2). Intakes of concentrate and total DM $(\mathrm{g} / \mathrm{d})$ increased linearly $(\mathrm{L}<0.0001)$ and quadratically $(\mathrm{P}<0.05)$ with increasing PDS level. Total DM intake $(\mathrm{g} / \mathrm{kg} \mathrm{LW})$ and average daily gain (ADG) increased (L: $P<0.0001 ; Q: P<0.05$ ) with increasing proportion of PDS in the diets. Total DM intake $(\mathrm{g} / \mathrm{kg} \mathrm{W0.75)}$ and CP intake were greater (L: $P<0.0001$ ) for PDS15 and PDS10 compared with PDS0 and PDS5. Intake of CT was higher $(P<0.0001$ for L and Q) for PDS15 than for PDS5 and PDS10.

Table 2. Feed utilization of ram-lambs fed processed Daniellia oliveri seed meal based diet

\begin{tabular}{|c|c|c|c|c|c|c|c|}
\hline \multirow[b]{2}{*}{ Parameters } & \multicolumn{4}{|c|}{ Diet } & \multirow[t]{2}{*}{ SEM } & \multicolumn{2}{|c|}{ P-value } \\
\hline & PDS0 & PDS5 & $\begin{array}{c}\text { PDS1 } \\
0\end{array}$ & PDS15 & & $\mathbf{L}$ & $\mathbf{Q}$ \\
\hline TST (g/d) & $285.7^{a}$ & $279.0^{\mathrm{a}}$ & $267.7^{b}$ & $243.0^{c}$ & 3.04 & $<0.0001$ & 0.003 \\
\hline $\begin{array}{l}\text { Concentrate } \\
\text { (g/d) }\end{array}$ & $667.0^{d}$ & $683.2^{c}$ & $724.3^{b}$ & $769.1^{\mathrm{a}}$ & 2.19 & $<0.0001$ & $<0.001$ \\
\hline $\begin{array}{l}\text { Total DM } \\
(\mathrm{g} / \mathrm{d})\end{array}$ & $953^{d}$ & $962^{c}$ & $992^{\mathrm{b}}$ & $1012^{\mathrm{a}}$ & 3.93 & $<0.0001$ & 0.044 \\
\hline $\begin{array}{l}\text { Total DM } \\
\text { (g/kg LW) }\end{array}$ & $51.98^{c}$ & $52.01^{c}$ & $53.84^{\mathrm{b}}$ & $56.90^{\mathrm{a}}$ & 0.62 & $<0.0001$ & 0.019 \\
\hline $\begin{array}{l}\text { Total DM } \\
\text { (g/kg W0.75) }\end{array}$ & $108^{b}$ & $108^{b}$ & $111^{\mathrm{a}}$ & $112^{\mathrm{a}}$ & 0.38 & $<0.0001$ & 0.287 \\
\hline $\begin{array}{l}\text { Crude } \\
\text { protein } \\
\left(\mathrm{g} / \mathrm{kg} \mathrm{W}^{0.75}\right)\end{array}$ & $18.96^{\mathrm{d}}$ & $19.51^{\mathrm{cd}}$ & $20.23^{b}$ & $20.50^{\mathrm{a}}$ & 0.22 & 0.001 & 0.501 \\
\hline $\begin{array}{l}\mathrm{CT}(\mathrm{g} / \mathrm{kg} \\
\left.\mathrm{W}^{0.75}\right)\end{array}$ & $0.18^{c}$ & $0.27^{b}$ & $0.29^{b}$ & $0.35^{\mathrm{a}}$ & 0.02 & $<0.0001$ & $<0.0001$ \\
\hline ADG (g/day) & $104^{c}$ & $105^{c}$ & $113^{b}$ & $120^{\mathrm{a}}$ & 1.37 & $<0.0001$ & 0.035 \\
\hline $\begin{array}{l}\text { Feed } \\
\text { conversion } \\
\text { ratio } \\
\end{array}$ & $9.14^{\mathrm{a}}$ & $9.18^{a}$ & $8.77^{b}$ & $8.43^{c}$ & 0.05 & $<0.0001$ & 0.001 \\
\hline
\end{tabular}

$\mathrm{a}, \mathrm{b}, \mathrm{c}$, means within a row not bearing a common superscript letter significantly differ, $(\mathrm{P}<0.05)$ TST, threshed sorghum tops; PDS, Processed Daniellia oliveri seed. CT, Condensed tannins. ADG, Average daily weight gain

\section{Rumen fermentation parameters and enteric methane production}

Diet effect on ruminal temperature was marginal. Ruminal $\mathrm{pH}$ was greater (L: $P<0.0001$; $: P=0.003$ ) in PDS15 than in other diets (Table 3). Ruminal NH3-N was more pronounced in PDS0 and PDS15, intermediate in PDS10 and lowest in PDS15, resulting in a linear response (L: $P<0.0001$ ). Ruminal TVFA 
was greater for PDS15 relative to PDS0 and PDS, producing linear trend $(P<$ 0.007). Whereas ruminal acetate, acetate to propionate ratio (C2:C3) and methane gas production decreased linearly $(P<0.0001)$, propionate (L: $P<$ 0.0001), valerate (L: $P<0.0001$ ) and isovalerate (L: $P<0.0001 ; \mathrm{Q}: P=0.003$ ) increased with increasing PDS level. Diet effect on ruminal butyrate was higher in PDS0 than other PDS diets (linear and quadratic, $P<0.01$ ).

Table 3. Rumen fermentation parameters and enteric methane production of ramlambs fed processed Daniellia oliveri seed meal-based diet

\begin{tabular}{|c|c|c|c|c|c|c|c|}
\hline \multirow[b]{2}{*}{ Parameter } & \multicolumn{4}{|l|}{ Diet } & \multirow[t]{2}{*}{ SEM } & \multicolumn{2}{|l|}{ P-value } \\
\hline & PDS0 & PDS25 & PDS50 & $\begin{array}{c}\text { PDS7 } \\
5 \\
\end{array}$ & & Linear & $\begin{array}{l}\text { Quadrati } \\
\text { c }\end{array}$ \\
\hline Tempt. $\left({ }^{0} \mathrm{C}\right)$ & 38.98 & 38.90 & 39.00 & 39.02 & 2.73 & 0.560 & 0.410 \\
\hline $\mathrm{pH}$ & $6.63^{a}$ & $6.60^{\mathrm{a}}$ & $6.58^{a}$ & $6.49^{b}$ & 0.05 & $<0.0001$ & 0.003 \\
\hline $\begin{array}{l}\mathrm{NH}_{3}-\mathrm{N} \\
(\mathrm{mg} / \mathrm{L})\end{array}$ & $173.0^{\mathrm{a}}$ & $170.0^{\mathrm{a}}$ & $164.0^{\mathrm{b}}$ & $160.0^{c}$ & 1.97 & $<0.0001$ & 0.645 \\
\hline TVFA (mM) & $117.3^{c}$ & $118.1^{b c}$ & $120.3^{\mathrm{ab}}$ & $122.0^{\mathrm{a}}$ & 1.02 & 0.007 & 0.614 \\
\hline VFAs (mol/10 & nol) & & & & & & \\
\hline Acetate $\left(\mathrm{C}_{2}\right)$ & $78.0^{\mathrm{a}}$ & $76.0^{\mathrm{b}}$ & $73.0^{c}$ & $71.0^{\mathrm{d}}$ & 0.71 & $<0.0001$ & 0.757 \\
\hline $\begin{array}{l}\text { Propionate } \\
\left(C_{3}\right)\end{array}$ & $26.0^{\mathrm{d}}$ & $30.0^{c}$ & $34.0^{\mathrm{b}}$ & $37.0^{\mathrm{a}}$ & 1.07 & $<0.0001$ & 0.530 \\
\hline Butyrate $\left(\mathrm{C}_{4}\right)$ & $9.8^{\mathrm{a}}$ & $8.5^{b}$ & $8.2^{\mathrm{bc}}$ & $8.0^{c}$ & 0.17 & $<0.0001$ & 0.001 \\
\hline $\begin{array}{l}\text { Iso-valerate } \\
\left(\mathrm{C}_{5}\right)\end{array}$ & $1.2^{\mathrm{d}}$ & $1.9^{c}$ & $2.3^{\mathrm{b}}$ & $2.8^{\mathrm{a}}$ & 0.05 & $<0.0001$ & 0.036 \\
\hline Valerate $\left(\mathrm{C}_{6}\right)$ & $1.4^{\mathrm{d}}$ & $2.2^{\mathrm{c}}$ & $2.5^{\mathrm{b}}$ & $3.0^{\mathrm{a}}$ & 0.11 & $<0.0001$ & 0.111 \\
\hline $\mathrm{C}_{2}: \mathrm{C}_{3}$ & $3.0^{\mathrm{a}}$ & $2.5^{b}$ & $2.2^{\mathrm{c}}$ & $1.9^{\mathrm{d}}$ & 0.12 & $<0.0001$ & 0.212 \\
\hline $\begin{array}{l}\mathrm{CH}_{4}(\mathrm{~mol} / 100 \\
\mathrm{mol})\end{array}$ & $24.0^{\mathrm{a}}$ & $22.6^{b}$ & $20.0^{c}$ & $18.6^{\mathrm{d}}$ & 0.16 & $<0.0001$ & 0.787 \\
\hline
\end{tabular}

\section{Rumen microbial population and classification}

Total ruminal bacterial population was highest for PDS15 and lowest for PDS0 and PDS5, resulting in linear and quadratic responses (L: $P<0.0001 ; \mathrm{Q}$ : $P=0.008$ ) (Table 4). Total protozoal population (linear and quadratic, $\mathrm{P}<$ 0.01 ) and Ophryoscolex (as \% of the total protozoal count) (Q: $P<0.0001$ ) were lower for PDS15 than for other treatments. Fungal population was highest in PDS10 and PDS15 and lowest in PDS0 (linear effect, P < 0.0001). Proteolytic bacterial numbers were lowest and highest in PDS0 and PDS15, producing linear and quadratic trends ( $\mathrm{L}$ and $\mathrm{Q}: P<0.0001$ ) respectively. Diet effect on cellulolytic bacteria and Holotrichs (as \% of the total protozoal count) were linear and quadratic (L: $P<0.0001$; Q: $P<0.05$ ), with PDS0 and PDS5 having the highest populations and PDS15 the lowest. Amylolytic bacterial population was higher in PDS15 compared to other diets (L and Q: P $<0.0001$ ). The populations of ruminal archea methanogens and Entodinium (as $\%$ of the total protozoal count) decreased (linear, $P<0.0001$; quadratic, $P$ 
$=0.0016$ ), as the PDS inclusion level increased. Diplodinium (as \% of the total protozoal count) was highest in PDS0, intermediate in PDS5 and lowest in PDS10 and PDS15, resulting in linear and quadratic trends ( $L$ and Q: $P<0.01$ ).

Table 4. Rumen microbial population and classification of ram-lambs fed processed Daniellia oliveri seed meal-based diet

\begin{tabular}{|c|c|c|c|c|c|c|c|}
\hline \multirow{2}{*}{$\begin{array}{l}\text { Rumen } \\
\text { Microbial } \\
\text { Biomass }\end{array}$} & \multicolumn{4}{|c|}{ Diet } & \multirow[t]{2}{*}{ SEM } & \multicolumn{2}{|c|}{ P-value } \\
\hline & PDS0 & PDS5 & $\begin{array}{c}\text { PDS1 } \\
0\end{array}$ & PDS15 & & Linear & $\begin{array}{c}\text { Quadrat } \\
\text { ic }\end{array}$ \\
\hline $\begin{array}{l}\text { Total viable } \\
\text { bacteria, } \\
\times 10^{8} \mathrm{cfu} / \mathrm{mL}\end{array}$ & $9.07^{\mathrm{c}}$ & $9.32^{\mathrm{c}}$ & $10.0^{\mathrm{b}}$ & $10.8^{\mathrm{a}}$ & 0.24 & $<0.0001$ & 0.008 \\
\hline $\begin{array}{l}\text { Total protozoa, } \\
\times 10^{4} \text { cell } / \mathrm{mL}\end{array}$ & $6.86^{\mathrm{a}}$ & $6.68^{a}$ & $6.48^{\mathrm{a}}$ & $5.07^{b}$ & 0.20 & $<0.0001$ & 0.002 \\
\hline $\begin{array}{l}\text { Total fungi, } \\
\times 10^{6} \mathrm{cfu} / \mathrm{mL}\end{array}$ & $6.67^{c}$ & $8.02^{b}$ & $8.70^{\mathrm{a}}$ & $9.27^{\mathrm{a}}$ & 0.26 & $<0.0001$ & 0.078 \\
\hline \multicolumn{8}{|c|}{ Bacteria class according to substrate fermented } \\
\hline $\begin{array}{l}\text { Proteolytic, } \\
\times 10^{6} / \mathrm{mL}\end{array}$ & $2.30^{\mathrm{c}}$ & $2.52^{\mathrm{b}}$ & $2.56^{\mathrm{b}}$ & $3.08^{a}$ & 0.02 & $<0.0001$ & $<0.001$ \\
\hline $\begin{array}{c}\text { Cellulolytic, } \\
\times 10^{7} / \mathrm{mL}\end{array}$ & $6.80^{\mathrm{a}}$ & $6.74^{\mathrm{a}}$ & $5.87^{\mathrm{b}}$ & $4.75^{c}$ & 0.10 & $<0.0001$ & 0.002 \\
\hline $\begin{array}{l}\text { Amylolytic, } \times 10^{6} \\
/ \mathrm{mL}\end{array}$ & $0.78^{c}$ & $0.85^{\mathrm{bc}}$ & $0.89 \mathrm{~b}$ & $1.28^{\mathrm{a}}$ & 0.03 & $<0.0001$ & $<0.001$ \\
\hline $\begin{array}{l}\text { Methanogenic } \\
\text { archaea, } \times 10^{8} \\
/ \mathrm{mL}\end{array}$ & $1.02^{\mathrm{a}}$ & $0.73^{b}$ & $0.67^{c}$ & $0.43^{\mathrm{d}}$ & 0.02 & $<0.0001$ & 0.016 \\
\hline \multicolumn{8}{|c|}{ Protozoa genera (as \% of total protozoa count) } \\
\hline Entodinium & $90.0^{\mathrm{a}}$ & $87.0^{\mathrm{b}}$ & $82.0^{c}$ & $79.5^{\mathrm{d}}$ & 0.52 & $<0.0001$ & 0.264 \\
\hline Diplodinium & $23.5^{\mathrm{a}}$ & $23.0^{\mathrm{ab}}$ & $22.0^{\mathrm{b}}$ & $21.0^{\mathrm{b}}$ & 0.58 & $<0.001$ & 0.006 \\
\hline Ophryoscolex & $6.10^{\mathrm{a}}$ & $6.32^{\mathrm{a}}$ & $6.42^{\mathrm{a}}$ & $6.00^{\mathrm{b}}$ & 0.07 & 0.358 & $<0.001$ \\
\hline Holotrich & $48.0^{\mathrm{a}}$ & $47.9^{\mathrm{a}}$ & $45.8^{\mathrm{b}}$ & $42.0^{c}$ & 0.82 & $<0.0001$ & 0.033 \\
\hline
\end{tabular}

$\mathrm{a}, \mathrm{b}, \mathrm{c}, \mathrm{d}$ means within a row not bearing a common superscript letter significantly differ, $(\mathrm{P}<0.05)$

\section{DISCUSSION}

The nutrient composition of TST is consistent with previous studies (Isah et al., 2015; Okunade et al., 2016; Okunade et al., 2018). The PDS is tannincontaining feedstuffs, but with much lower contents than the threshold level at which tannins impair nutrient utilization and performance in ruminants. This might probably be due to the effect of heat treatment and decortications of the Daniellia oliveri seed during processing. The low CP and high fibre fractions contents of TST confirm it as a typical low-quality roughage diet, with low feeding value that cannot meet the requirements of ruminants in various physiological states without supplementation. The CP content of the 
supplementary concentrates met requirement of $180 \mathrm{~g} / \mathrm{kg}$ DM recommended for growing sheep (MLA, 2007), while NDF content was far below the 650 $\mathrm{g} / \mathrm{kg}$ DM threshold level at which cell wall inhibits feed intake, digestibility and animal performance (Meissner et al., 1991).

Higher concentrate intake of PDS15 indicates increased palatability and hence, acceptability and consumption (Kholif et al., 2018a; Olafadehan et al., 2018). Higher voluntary intake of PDS15 resulted in the higher CP intake for the lambs. It has been shown that CP intake is a major determinant of ruminant performance due to increased availability of fermentable CP and other nutrients required by rumen bacteria as well as a greater opportunity for dietary protein to escape rumen fermentation (Conte et al., 2010). Although CT concentration and intake increased with increasing PDS in the diet, highest concentrate intake and ADG of sheep on the PDS15 confirms the moderate and beneficial level of its CT because CT at a high concentration is harmful and impairs palatability, feed consumption, protein metabolism, nutrient digestibility and weight gain (Isah et al., 2015; Olafadehan et al., 2014a, 2020). Therefore, the CT concentration of $3.02 \mathrm{~g} / \mathrm{kg} \mathrm{DM}$ of the PDS15 did not compromise palatability as to adversely affect consumption and ADG. The linear increase in the concentrate diets intake suggests that PDS is more palatable than GNC. Toasted legume seeds are characterized by unique flavours which increase their sensory appeal to animals (Raji et al., 2014). Furthermore, the highest total DM intake in PDS15 diet could be attributed to the fibre level, which decreased progressively with increasing PDS replacement for GNC. This must have reduced gut fill and improved the rate and extent of ruminal degradation, resulting in a faster passage of the digesta through the gastrointestinal tract and a shorter retention time (Kang et al. 2012; Okunade et al., 2014b; Olafadehan et al., 2014a). In spite of the lowest basal TST intake of the PDS15 diet supplemented sheep, overall DM intake was highest for the animals. Since both the basal TST and supplementary diet contained CT, the result indicates that the dietary CT was well tolerated by animals and did not induce tannin toxicosis (Olafadehan et al., 2014a) which affects rumen microbiota and fermentation, feed utilization and growth performance. The generally high acceptability of all the diets by the lambs is further confirmed by the relatively high DM consumption (expressed as $\mathrm{g} / \mathrm{kg}$ LW), which increased from 51.98 to $56.9 \mathrm{~g} / \mathrm{kg} \mathrm{LW}$ as the PDS level increased. Feed intake (g/kg LW), in the current study, is higher than the 3-4 g/ kg LW generally recommended for ruminants. Intakes expressed as the metabolic were within the range of 3.9 to $6.3 \mathrm{~g} / \mathrm{kg} \mathrm{LW}$ obtained for the Yankasa lambs (Olafadehan et al., 2014b; Isah et al., 2015; Okunade and Olafadehan, 2019). Dry matter intake is a key determinant of growth of animals; therefore, in response to feed intake, ADG also increased as the PDS increased. The improved FCR of the PDS diets confirm the previous submission that the CT of 
the diets was moderate, well tolerated and did not interfere with nutrient metabolism, absorption and utilization, in agreement with earlier reports (Olafadehan et al., 2020).

Tannin-containing diets modified rumen fermentation parameters in this study, in accordance with the reports of Belanche et al. (2019). Ruminal temperature measurement is a suitable and feasible means to detect potential adverse alteration in the health of animals in real time (Wahrmund et al., 2012). The unaffected rumen temperature was maintained within the recommended range of 39 to $39.5^{\circ} \mathrm{C}$ (Wahrmund et al., 2012) which suggests that lambs had no health challenge. No external factor can alter intraruminal temperature, although it is approximately $0.5^{\circ} \mathrm{C}$ higher than core body temperature due to the activity of heat-producing rumen microorganisms (Bodas et al., 2014).

Ruminal $\mathrm{pH}$ was within optimal range (6.2 - 7.2) for normal rumen ecology and fermentation (Gunun et al., 2013; Isah et al., 2013). The PDS15 diet with the highest NFC and lowest fibre fractions had the lowest ruminal $\mathrm{pH}$. High VFA and lactic acid production, as a result of rapid ruminal fermentation of dietary readily fermentable carbohydrates and reduced chewing time and salivation rate due to low dietary fibre level, have been reported to lower ruminal $\mathrm{pH}$ (Olafadehan et al., 2016; Olafadehan and Adebayo, 2016).

Concentration of NH3-N in the rumen fluid is the net result of NH3-N production from feed, protein fermentation, absorption rate through the rumen wall, passage out of the rumen and utilization by microbes. Ruminal NH3-N concentrations in all the treatments were within the optimal ruminal range of 150 - $200 \mathrm{mg} / \mathrm{L}$ for optimal ruminal ecology, fermentation and microbial growth (Perdok and Leng, 1990). Decreased ruminal NH3-N concentration of PDS diets indicates lower ruminal CP degradability of PDS, due to its CT, relative to GNC. The result indicates higher bypass protein value of PDS than GNC.

Increased ruminal VFA concentration of PDS15 diet may be a direct result of its highest readily fermentable NFC content ((Wanapat et al., 2014; Olafadehan et al., 2016; Okunade and Olafadehan, 2019)) and enhanced ruminal fermentation (Kholif et al., 2018b). The ruminal VFA concentrations of all the animals were within the normal range for ruminants. The linear increase in ruminal propionate may be due to progressive increase in feed intake as the PDS proportion increased in the diet. Therefore, low ruminal propionate in animals fed PDS0 diet might be as a result of low DM intake (Isah et al., 2014) and reduced ruminal fermentation due to its relatively low NFC content. The higher rumen propionate concentration of the lambs fed the PDS, particularly PDS15, is beneficial as it must have enhanced energy availability for improved nutrient utilisation and ADG. The linear decrease in 
molar proportion of ruminal acetate may be related to the decrease in fibre level of the diets as PDS inclusion level increased. Opsi et al. (2012) affirmed that ruminal acetate production is due majorly to structural carbohydrate fermentation by cellulolytic bacteria, while propionate production is due to NFC degradation by amylolytic bacteria. In the current study, structural carbohydrates were higher in control diet (PDS0) while NFC was higher in the PDS diets. Highest cellulolytic bacteria and lowest amylolytic bacteria numbers in the control diet than in the PDS diets further explained the result.

Propionate formation can be considered as a competitive pathway for CH4 production (Moss et al., 2000). Therefore, the increased ruminal propionate concentration of the PDS diets led to the reduction of $\mathrm{CH} 4$ production. Condensed tannins suppressed $\mathrm{CH} 4$ production by redirecting hydrogen from the CH4 pathway to produce propionate (Wanapat et al., 2014). Similarly, Animut et al. (2008) and Olafadehan and Okunade (2018) reported increased propionate and reduced $\mathrm{CH} 4$ production with CTcontaining forage. Plant secondary metabolites, particularly CT and saponins, have been shown to reduce protozoa and archea methanogens, resulting in methanogenesis suppression (Wanapat et al., 2014; Gunun et al., 2016). It is plausible to aver that PDS can be used as an environmentally friendly feedstuff to abate enteric methane emission for sustainable environment and ruminant production.

The microbial population in this study revealed an unequal number among the typical rumen microbes enumerated. Bacterial species had the largest population compared to other microbial populations. It is, therefore, likely that bacteria are responsible for the major part of ruminal feed degradation and are the main drivers behind the observed differences (Kamra, 2005). The highest bacteria population with PDS15 diet could be as a result of its decreased protozoa population. Decreased ruminal protozoa population has been reported to result in an increase in bacterial population (Carberry et al., 2012; Isah et al., 2013) because protozoa engulf bacteria. This implies that CT concentration in the PDS15 diet made a significant reduction in the protozoa population. Since both protozoa and methanogens are closely related, archaea methanogens population was also lowest in PDS15. Earlier studies (Makkar et al., 1995; Guo et al., 2008) reported reduction in protozoa and methanogens populations due to the effect of tannins.

The increased ruminal fungi population with PDS15 could be due to the interaction between protozoa and fungal zoospores. Newbold and Hillman (1990) also noted an increase in the numbers of fungal zoospores when protozoa were removed from the rumen. The increased bacterial and fungal populations and reduced protozoal and methanogens populations with the PDS15 diet are nutritionally and environmental beneficial due to improved 
nutrient availability and utilisation for weight again and methane production abatement.

Proteolytic bacterial population increased progressively with the increasing PDS level, with the highest population in PDS15 diet. This increase might be as a result of reduction in the number of protozoa as well as increase in CP intakes of the PDS diets, as opined by Nguyen et al. (2017). Also, the inhibitory effect of CT may lower the activities of cellulolytic bacteria and consequently allows the proteolytic bacteria to compete more effectively for nutrients, thus increasing their relative abundance (Wolin and Miller, 1988). On the contrary, cellulolytic bacterial population decreased with increasing PDS level, which could be as a result of many factors including interactions between the cellulolytic and proteolytic bacterial populations and changes in digesta composition and rate of outflow from the rumen (Mcsweeney et al., 2001).

Present study showed that Entodinium is the most dominant protozoa genera followed by Holostrichs then Diplodinium, while Ophryoscolex was the least in population in the rumen of the lambs. This result corroborates the presence of protozoal population found in rumen liquor of sheep fed Dicantium annulatum grass supplemented with Leucaena and Haedwickia tree leaves (Singh and Kundu, 2011). Both Diplodinium and Ophryoscolex general had the lowest population, in agreement with the observations of earlier workers (Mughetti et al., 2007) who noted Ophryoscolex in the range of 5.51 to $7.17 \%$ in rumen of sheep. Lowest populations of the protozoa genera in the PDS diets relative to the control diet could be explained by the reduction in the total protozoal count in the treatment diets, particularly in the PDS15 diet with highest CT concentration. Since protozoa are generally associated with fibre digestion, the highest populations of the protozoa genera in the control diet could be attributed to its pronounced dietary fibre level and consumption of the basal TST roughage diet. Generally, high forage diets favour cellulolytic microbes and make them preponderance while low-forage diets result in lower number of cellulolytic microbes. This may account for the higher population of Entodinium and Diplodinium in the PDS0 (control diet) relative to the PDS diets. About 16 to $30 \%$ of total rumen \microbial fibre digestion was done by protozoa (Jabari et al., 2014) who indicated that ability of Entodinium, Epidinium and Diplodinium to degrade cellulose, hemicellulose and NDF was high. Ophryoscolex and Holotrichs are ciliate protozoa speculated to help in fibre digestion, although their specific role in rumen ecosystem remains controversial (Newbold, 2015).

\section{CONCLUSION}

Processed (toasted and seed coat decorticated) Daniellia oliveri seed meal, particularly $150 \mathrm{~g} / \mathrm{kg}$ inclusion level, improved feed utilisation, ruminal 
fermentation efficiency and growth performance, altered ruminal microbiota and reduced methane production. The seed meal can be used as an alternative protein source to replace up to $75 \%$ of groundnut cake in a supplementary concentrate for growing lambs consuming low-quality basal diet. Further research on complete replacement of processed Daniellia oliveri seed meal for groundnut cake is warranted.

\section{REFERENCES}

AOAC., 2000. Official Methods of Analysis. 17th Ed. Association of Analytical Chemists, Arlington, Virginia, Usa.

Animut, G., R., Puchala, A. L., Goetsch, A.K., Patra, T., Sahlu, V.H., Varel, and Wells. J., 2008. Methane emission by goats consuming different sources of condensed tannins. Animal Feed Science Technology, 144:228-241.

Belanche, A., Alison, H., Smith, k., Griffith, G.W., Newbold, C.J., 2019. A MultiKingdom study reveals the plasticity of the rumen microbiota in response to a shift from non-grazing to grazing diets in sheep. Frontiers in Microbiology, 10 (22), doi: 10.3389/fmicb.2019.00122.

Benchaar, C., Petit, H.V., Berthiaume, R., Ouellet, D.R., Chiquette, J., 2003. Effects of essential oil supplements on ruminal fermentation, rumen microbial populations and in sacco degradation of dry matter and nitrogen in the rumen of lactating dairy cows. Canadian Journal of Animal Science, 83, 637-638.

Bodas, R., Posado, R., Daniel José Bartolomé, D.J., Tabernero de Paz, M.J., Herráiz, P., Rebollo, E., Gómez, L.J., García, J.J., 2015. Ruminal pH and temperature, papilla characteristics, and animal performance of fattening calves fed concentrate or maize silage-based diets. Chilean Journal of Agricultural Research, 74(3): 280-285.

Carberry, C.A., Kenny, D.A., Han, S., McCabe, M. S., Waters, S. M., 2012. Effect of phenotypic residual feed intake and dietary forage content on the rumen microbial community of Beef Cattle. Applied Environmental Microbiology, 78 (14): 4949-4958.

Conte, G., Ciampolini, R., Cassandro, M., Lasagna, E., Calamari, L., Bernabucci, U., Abeni, F., 2018. Feeding and nutrition managementof heat-stressed dairy ruminants. Italian Journal of Animal Science, 17:3, 604-620.

D' agosto., M. T. and Carneiro, M. E. 1999. Evaluation of Lugol Solution used for Counting Rumen Ciliates. Revista Brasileira de Zoologia, 16 (3): 725729.

Dehority, B.A., Tirabasso. P.A. Grifo. A.P., 1989. Most-probable-number procedures for enumerating ruminal bacteria, including the simultaneous estimation of total and cellulolytic numbers in one medium. Applied Environmental Microbiology, 55: 2789-2792. 
Gunun, P., Wanapat, M., Cherdthong, A., 2013. Manipulation of ruminal fermentation and methane production by supplementation of rain tree pod meal containing tannins and saponins in growing dairy steers. Journal of Animal Physiology and Animal Nutrition, 98(1): 112- 130.

Gunun, P., Wanapat, M., Gunun, N., Cherdthong, A., Sirilaophaisan, S., Kaewwongsa, W., 2016. Effects of condensed tannins in mao (Antidesma thwaitesianum Muell. Arg.) seed meal on rumen fermentation characteristics and nitrogen utilization in goats. AsianAustralasian Journal of Animal Science, 29(8):111-119.

Guo, Y.Q., Liu, J.X., Lu, Y., Zhu, W.Y., Denman, S.E., McSweeney, C.S., 2008. Effect of tea saponin on methanogenesis, microbial community structure and expression of mcrA gene, in cultures of rumen microorganisms. Letters Applied Microbiology, 47, 421-426.

Isah, O. A., Oguntuyo, S. A., Dawodu, R. O., Diya, O. O., Afolabi, M.O. and Omoniyi, L.A. 2013. Feed Utilization, Rumen Parameters (Rumen Microbial Profile of Goats Fed Different Browse Plants with P. purpuretumas Basal Diet. Pacific Journal of Science and Technology, 14 (1): $397-405$.

Isah, O. A., Okunade, S. A., Aderinboye, R. Y. and Oyekunle, M. A. 2014. Rumen fermentation and microbial profile of Red Sokoto goats fed threshed sorghum top supplemented with browse foliages. Tropical Animal Production Investigation, 17 (1), 67-73.

Isah, O. A., Okunade, S. A., Aderinboye, R.Y., Olafadehan, O.A., 2015. Effect of browse plant foliage supplementation on the performance of buckling goats fed threshed sorghum top basal diet. Tropical Animal Health and Production, 47(6):1027-1032.

Jabari, S., Eslami, M., Chaji, M., Mohammadabadi, T., Bojarpour, M., 2014. Comparison digestibility and protozoa population of Khuzestan water buffalo and Holstein cow. Veterinary Research Forum, 2014; 5:295 300 .

Joblin, K. N., 1981. Notes; isolation, enumeration and maintenance of rumen anaerobic fungi in roll tubes. Applied and Environmental Microbiology, 42:1119-1122.

Kamra, D. N., 2005. Rumen microbial ccosystem. Current Science, 89(1): 124135.

Kang, S., Wanapat, Pakdee, P., Pilajun, R., Cherdthong, A., 2012. Effects of energy level and Leucaena leucocephala leaf meal as a protein source on rumen fermentation efficiency and digestibility in swamp buffalo. Animal Feed Science and Technology, 174, 131-139.

Kayol, L. T. and Borilek, G. O. D. 1995. Spectrophotometric Determination of Volatile Fatty Acids. Analytical Chemist, 34: 112-117. 
Kholif, A.E., Gouda, G.A., Olafadehan, O.A., Abdo, M.M., 2018a. Effects of replacement of Moringa oleifera for berseem clover in the diets of Nubian goats on feed utilisation, and milk yield, composition and fatty acid profile. Animal, 12(5): 964-972.

Kholif, A.E., Gouda, G.A., Anele, U.Y., Galyean, M.L., 2018b. Extract of moringa oleifera leaves improves feed utilization of lactating nubian goats. Small ruminant Research, 158: 69-75.

Makkar, H.P.S., Borowy, N.K., Becker, K., Degen, A., 1995. Some problems in fiber determination of a tannin-rich forage (Acacia saligna leaves) and their implication in in vivo studies. Animal Feed Science and Technology, 55: 67-76.

McSweeney, C. S., Palmer, B., Bunch, R., Krause, D. O., 2001. Effect of the tropical forage calliandra on microbial protein synthesis and ecology in the rumen. Journal of Applied Microbiology, 90: 78-88.

Mebrahtu, T., 1992. Growth and photosynthesis of black locust. Proceedings of the International Conference on Black Locust: Biology, Culture and Utilization June 17-21 Michigan State University, East Lansing, MI.

Meissner, H. H., Viljoen, M. O., Van Niekerk, W.A., 1991. Intake and Digestibility by Sheep of Anthephora, Panicum, Rhodes and Smuts Finger Grass Pastures. In: Proccedings of the IVth International Rangeland Congress, 22-26 April 1991, Montpellier, France, pp. 648-649.

MLA., 2007. Meat and Livestock Australia Limited. Assessed from: www.mla.com.au.

Moss, A. R., Jouany, J.P., Newbold, J., 2000. Methane production by ruminants: its contribution to global warming. Animal Research, 49:231-253.

Newbold, C. J., Hillman, K., 1990. The effect of ciliate protozoa on the turnover of bacterial and fungal protein in the rumen of sheep. Letters Applied Microbiology, 11, 100-102.

Newbold, C.J., de la Fuente, G., Belanche, A., Ramos-Morales, E., McEwan, N.R., 2015. The role of ciliate protozoa in the rumen. Frontiers in Microbiology, 6:1313. doi:10.3389/fmicb.2015.01313.

Nguyen, T.T.G., Wanapat, M., Phesatcha, K., Kang, S., 2017. Effect of inclusion of different levels of leucaenasilage on rumen microbial population and microbial protein synthesis in dairy steers fed on rice straw. AsianAustralasian Journal of Animal Science, 30(20): 181-186.

Ogimoto, K., Imai, S., 1981. Atlas of Rumen Microbiology. Japan Scientific Society Press Tokyo, Japan.

Okunade, S.A., Isah, O.A Aderinboye, R.Y. and Olafadehan, O.A. 2014a. Assessment of chemical composition and in vitro degradation profile of some guinea savannah plants of Nigeria. Tropical and Subtropical Agroecosystems, 17: 529 - 538. 
Okunade, S.A., Olafadehan, O.A., Isah, O.A., 2014b. Fodder potential and acceptability of selected tree leaves by goats. Animal Nutrition and Feed Technology, 14, 489-498.

Okunade, S. A., Isah, O. A., Oyekunle, M. A., Olafadehan, O. A., Makinde, O.J., 2016. Effects of supplementation of threshed sorghum top with selected browse plant foliage on haematology and serum biochemical parameters of red sokoto goats. Tropical Animal Health and Production, 48(5): 979-984.

Okunade, S. A., Olafadehan, O. A., Adebayo, B. J. and Omole, E. B., 2018b. Intake, growth performance and economics of production of yankasa rams fed ammoniated ensiled threshed sorghum top supplemented with varying concentrate regimes. Nigerian Society for Animal Production, 45(5): $176-183$

Okunade, S.A., Olafadehan, O.A., 2019. Rolfe (Daniellia oliveri) seed meal as a protein source in locally produced concentrates for lambs fed low quality basal diet. Journal of the Saudi Society of Agricultural Sciences, 18 83-88

Olafadehan, O.A., Adewumi, M.K., Okunade, S.A. 2014a. Effects of feeding tannin-containing forage in varying proportion with concentrate on the voluntary intake, haematological and biochemical indices of goats. Trakia Journal of Sciences, 12: 73-81.

Olafadehan, O.A., Okunade, S.A. and Njidda, A.A. 2014b. Evaluation of bovine rumen content as a feed ingredient for lambs. Tropical Animal Health and Production, 46: 939-945.

Olafadehan, O.A., Adebayo, O.F., 2016. Nutritional evaluation of ammoniated threshed sorghum top as a feed for growing goats. Tropical Animal Health and Production, 48, 785-791.

Olafadehan, O.A., Njidda, A.A., Okunade, S.A., Adewumi, M.K., Awosanmi, K.J., Ijanmi, T.O., Raymond, A., 2016. Effects of feeding Ficus polita foliagebased complete rations with varying forage: concentrate ratio on performance and ruminal fermentation in growing goats. Animal Nutrition and Feed Technology, 16, 373-382.

Olafadehan, O.A., Okunade, S.A., 2018. Fodder value of three browse forage species for growing goats, Journal of the Saudi Society for Agricultural Sciences, 17, 43-50

Olafadehan, O.A., Okunade, S.A., Njidda, A.A. Kholif, A.E., Kolo, S.G., Alagbe, J.O., 2020. Concentrate replacement with Daniellia oliveri foliage in goat diet. Tropical Animal Health and Production, 52: 227-233.

Opsi, F., Fortina, R., Tassone, S., Bodas, R. López, S. 2012. Effects of inactivated and live cells of saccharomyces cerevisiae on in -vitro ruminal fermentation diets with different forage: concentrate ratio. Journal of Agricultural Science, (150): 271-283. 
Patra, A.K., Saxena, J., 2011. Exploitation of dietary tannins to improve rumen metabolism and ruminant nutrition. Journal of the Science of Food and Agriculture, 91:24 - 37

Perdok, H. B., Leng, R. A., 1990. Effect of supplementation with protein meal on the growth of cattle given a basal diet of untreated or ammoniated rice straw. Asian-Australian Journal Animal Science 3: 269-279.

Polshettiwar, S. A., Ganjiwale, R. O., Wadher, S. J., Yeole, P. G., 2007. Spectrophotometric estimation of total tannins in some ayurvedic eye drops. Indian Journal of Pharmaceutical Science, 69 (4): 574- 576.

Raji, M. O., Adeleye, O. O., Osuolale, S. A., Ogungbenro, S. D., Ogunbode A. A., Abegunde, P. T., Mosobalaje, M. A., Oyinlola, O. O., Alimi, I. O., Habeeb, A.A., 2014. Chemical composition and effect of mechanical processed of African yam bean on carcas characteristics and organs weight of broiler finisher. Asian Journal of Plant Science and Research, 4(2):1-6.

Singh, S., Kundu, S. S., 2011. Comparative rumen microbial population in sheep fed dicantium annulatum grass supplemented with Leucaena leucocephala and Hardwickia binata tree leaves. Livestock Research Rural Development, 23(1)

Van Soest, P. J., Robertson, P. J. and Lewis, B. A. 1991. Methods for dietary fiber, neutral detergent fiber and non-starch polysaccharides in relation to animal nutrition. Journal of Dairy Science, 74, 3583 - 3597.

Wahrmund, J. L., Ronchesel, J. R., Krehbiel, C. R., Goad, C. L., Trost, S. M., Richards, C. J., 2012. ruminal acidosis challenge impact on ruminal temperature in feedlot cattle. Journal of Animal Science, 90: 27942801.

Wanapat, M., Chanthakhoun, V., Phesatcha, K., Kang, S., 2014. Influence of mangosteen peel powder as a source of plant secondary compounds on rumen microorganisms, volatile fatty acids, methane and microbial protein synthesis in swamp buffaloes. Livestock Science, 162: 126-133.

Wolin, M.J., Miller, T.L., 1988. Microbe-microbe interactions. In The rumen microbial ecosystem (ed. PN Hobson), pp. 343-359. Elsevier Science. 